\title{
Roles of MSIE Graduates to Support Thailand Sustainable Smart Industry
}

\author{
Pisut KOOMSAP ${ }^{\mathrm{a}, 1}$, Huynh T. LUONG ${ }^{\mathrm{a}}$, Rui M. LIMA ${ }^{\mathrm{b}}$, Tomasz NITKIEWICZ ${ }^{\mathrm{c}}$, \\ Wichai CHATTINNAWAT ${ }^{d}$ and Duangthida HUSSADINTORN NA AYUTTHAYA ${ }^{a}$ \\ a Industrial Systems Engineering, Asian Institute of Technology, Thailand \\ ${ }^{\mathrm{b}}$ Production and Systems, University of Minho, Portugal \\ ${ }^{\mathrm{c}}$ Regionalism and Management of Sustainable Development, Czestochowa University \\ of Technology, Poland \\ ${ }^{\mathrm{d}}$ Industrial Engineering, Chiang Mai University, Thailand
}

\begin{abstract}
The way business run has changed in recent decades due to technology advancement, and it has become more explicit in many parts of the world that companies have been moving from stand-alone technology exploitation towards holistically integrated technology exploitation. Thailand's government has also foreseen the need for change from a production-based economy to a value-based economy and has encouraged the Thai industry to focus more on producing innovative products and services which require high potential and skilled knowledge workers. Consequently, their roles will never be the same. This paper presents findings on the expected roles of graduates with a Master degree in Industrial Engineering (MSIE) drawn from an industry survey on industry needs to attain Industry 4.0 conducted with companies based in Thailand and in three European countries participating in Erasmus+ Capacity Building in Higher Education project on Curriculum Development of Master's Degree Program in Industrial Engineering for Thailand Sustainable Smart Industry (MSIE 4.0). From the survey results, top-three technologies for being competitive and areas of applications to attain industry 4.0 in the companies' perspective were identified. Roles of MSIE graduates were determined for individual potential applications generated from identified technology-application relationships. According to the findings, the graduates are expected in general to play an important role in effective utilization of big data and real-time data for better decision making on various industrial practical problems as well as for better responsiveness to customers. The same procedure can be applied in other disciplines for identifying the roles of their graduates.
\end{abstract}

Keywords. Industry 4.0, Industry Survey, MSIE, Industrial Engineering, Thailand 4.0

\section{Introduction}

Advancement of technology, especially the introduction of the internet and the rapid progress of microelectronic technology, has changed customer behavior significantly. Today, customers can easily acquire products from anywhere whenever they need. They have access to nearly all products' information, study them and make a decision even before they step into a store. A competitive environment empowers customers to demand better responsiveness and forces companies to deliver timely quality products

\footnotetext{
${ }^{1}$ Corresponding Author, Email: pisut@ait.asia.
} 
and services to satisfy customer expectations. As a result, companies are being forced to change the way they conduct business. It has become more explicit in many parts of the world that the companies have been moving from utilizing technologies individually (Industry 3.0) to applying information technology to connect technologies together (Industry 4.0). This connectivity allows to better respond to customer needs in order to secure and sustain its business in an open competitive global market. Two key factors of Industry 4.0 are accessibility to information when needed and the ability to exploit it effectively.

For Thailand, the majority of companies, according to the Bureau of Supporting Industries Development of Thailand from one public seminar, are not ready for Industry 4.0. In fact, many of them are still below Industry 3.0, but the Thai government has foreseen the need for change and set a national policy to move from a production-based economy to a value-based economy in order for Thai industries to be competitive. Technology and creativity will be new driving forces for Thailand economy. Instead of trying to effectively produce commodity products in mass or of being OEM, the Thai companies have been encouraged to focus more on producing innovative products and services which require high potential and skilled knowledge staffs, but Rome cannot be built in a day. Many aspects will need to be improved and prepared, including capacity building. Therefore, human resource development for all levels is indispensable for the realization of this change, and there is no exception to industrial engineering discipline.

Higher education institutions (HEI) and industrial companies are both responsible for the development of competent engineering professionals. Nevertheless, there is a tendency of these organizations to do this work in different ways and with a lack of interaction. Most of the times, HEIs focus on knowledge transmission while industrial companies look for professionals with the development of specific competences useful for performing functions they need. HEIs try to get knowledge into the student's heads that will not be aligned with the competences they will need, not preparing them for the needs of the industrial companies [1]. Lima and colleagues [2] argue that "the alignment between an initial formation and professional practice demands studies that are able to identify the competences which are useful for professionals". These authors define the professional profile as being composed of three dimensions, namely: competences, knowledge areas and functions. Considering this approach, a study about the industry needs may include the areas of knowledge more useful for a profession, the most common functions those professional will perform and finally the competences they will need to perform those functions.

This paper presents the expected roles of graduates with a Master's degree in Industrial Engineering to support Thailand sustainable smart industry drawn from findings from a survey on industry needs to attain Industry 4.0. The survey was conducted under Erasmus + Capacity Building in Higher Education project on Curriculum Development of Master's Degree Program in Industrial Engineering for Thailand Sustainable Smart Industry (MSIE 4.0) by a consortium composing of six universities from Thailand and three universities from Europe. The six universities from Thailand are Asian Institute of Technology, Chiang Mai University, Khon Kaen University, Prince of Songkla University, Thammasat University, and King Mongkut's University of Technology North Bangkok. Three European universities are University of Minho, Czestochowa University of Technology and University Politechnica of Bucharest. 


\section{Industrial Engineering}

Industrial Engineering can be defined as an engineering field related to the project, improvement, and management of systems composed by people, materials, equipment, financial resources, information, and energy, that deliver products and services [3]. The diversity within the IE field reflects on the curriculum organization, which implies an interdisciplinary approach, bringing together the different areas of knowledge that IE integrates. The context of Industry 4.0 is challenging the industries for change (e.g., connect technologies together) and, for that reason, preparing industrial engineers for these challenges is mandatory. It is an opportunity to re-think curricula, pedagogical practices and the competences that students need to develop to be prepared for this challenging environment.

Based on the industrial engineering and management areas of knowledge presented by Lima and colleagues [4], the areas of knowledge in industrial engineering can be extended with additional areas (marked with *) and the updated list is as follow:

1. Automation

2. Economics Engineering

3. Ergonomics and Human Factors

4. Industrial Optimization

5. Maintenance

6. Marketing

7. Product Design

8. Production Management

9. Quality

10. Project Management

11. Supply Chain Management

12. Computer and Information Systems*

13. Industrial Engineering and Management*

14. Innovation and Entrepreneurship*

15. Research Methods*

16. Sociology and Law*

17. Sustainability*

18. Systems Design*

19. Other*- refers to other areas that can be identified in the courses and are not commonly included in IE programs. An example could be a course of "English for Industry".

\section{Research Methodology}

In order to identify the roles of graduates with Master's degree in Industrial Engineering to support Thailand sustainable smart industry, a survey on industry needs to attain Industry 4.0 was conducted. A questionnaire was formulated based on the "Industry 4.0 Readiness" study, which was commissioned by the IMPULS Foundation of the German Engineering Federation (VDMA) and conducted by IW Consult (a subsidiary of the Cologne Institute for Economic Research) and the Institute for Industrial Management (FIR) at RWTH Aachen University [5]. Moreover, it was also partially inspired on the "Industry 4.0 Self-Assessment" web tool from PricewaterhouseCoopers [6]. 
The questionnaire was for assessing the current level of development of industry at both management and operational levels. The industry need assessment would be summarized according to the following structure:

A. Strategy Level

1. What is the existing strategy level of business operation with respect to Industry 4.0 concepts?

2. What are the short-term plan for business direction and business strategy to gain competitiveness?

3. What are the policy, financial plan, HR plan, of the company toward adopting the industry 4.0 ?

B. Adoption Level - Domains of application

1. What is the existing level of manufacturing operation with respect to Industry 4.0 concepts?

2. What areas of Industry 4.0 they need to increase the company competitiveness or competences?

3. What are the current existing levels of development regarding main domains of industry 4.0 ?

The survey was conducted with 72 companies of which 50 of them are based in Thailand and the remaining are based in Portugal, Poland and Romania, the three European members of a consortium for Erasmus + Capacity Building in Higher Education project on Curriculum Development of Master's Degree Program in Industrial Engineering for Thailand Sustainable Smart Industry (MSIE 4.0). As illustrated in Figure 1, the top-three industry sectors with a higher number of answers in this survey are Manufacturing, Electronics and Automotive respectively, consisting of more than $60 \%$ of the sample.

The survey results were collected, analyzed, followed by a few sessions of brainstorming when the expected roles of MSIE graduates were drawn. Please be noted that selected outcomes are presented and discussed in the next section.

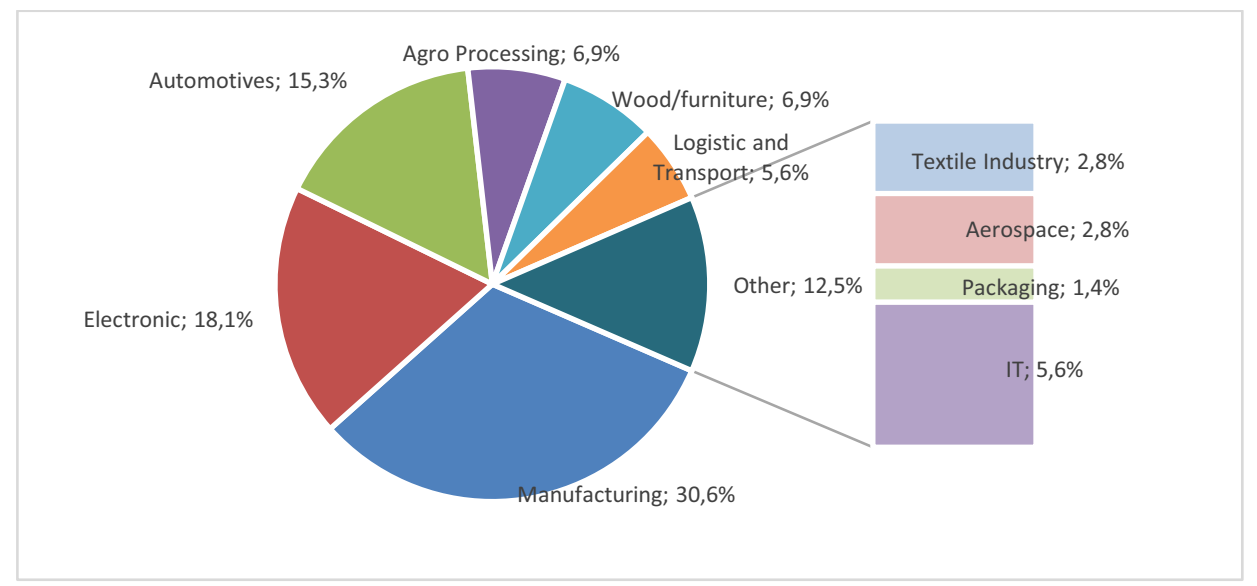

Figure 1. Classification of 72 companies by industrial sectors. 


\section{Results and Discussions}

\subsection{Voices from industry}

In the survey, the issues of the current strategy level regarding the implementation of Industry 4.0 and of technology adoption of companies were raised. The following domains of Industry 4.0 concept application were used to structure the analysis of industry needs concerning its adoption level: (1) Smart Products and Co-created Design, (2) Smart Factory, (3) Smart Operations and (4) Data Driven Services. The underlying assumption here is that MSIE graduates should support industry driven exploration and development within the strategic level and application domains in order to grant competitive advantage companies involved in the process. These four domains need graduates with wide spectrum of competences, and through the survey, they have been defined, assessed and possibly narrowed to the most significant and desired from the industrial point of view.

Concerning the strategy level, majority of the companies do not have an Industry 4.0 strategy formulated and implemented (66\% of Thai and 90\% EU companies, respectively) as shown in Figure 2. Thailand based companies seem to be more advance while strategy formulation is concerned, and similar situation is for its operationalization through the system of progress indicators (Figure 3). Besides, investment activity relating to Industry 4.0 is significantly low. More than $50 \%$ of the respondents are not strongly engaged in investments for industry 4.0 implementation in the past two years, in most of the areas except IT, which gets medium or large investments for about half of companies participating in the questionnaire. The survey further revealed the areas where companies consider to have a systematic technology and innovation management. Production technology (about 62\% of responding companies), IT ( $>40 \%)$ and product development $(>40 \%)$ as illustrated in Figure 4 are the main targets for the implementation of Industry 4.0.

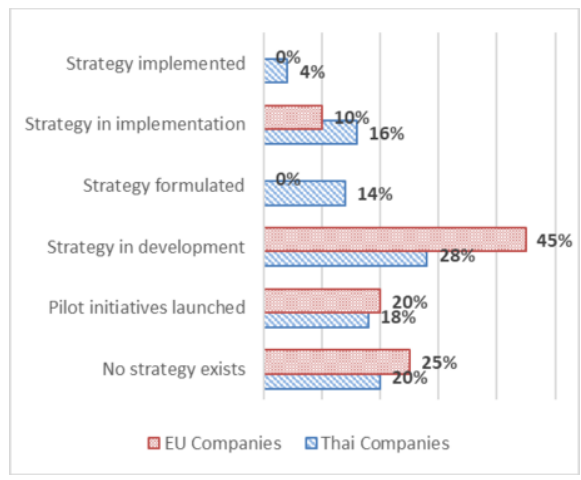

Figure 2. Implementation status of Industry 4.0 strategy.

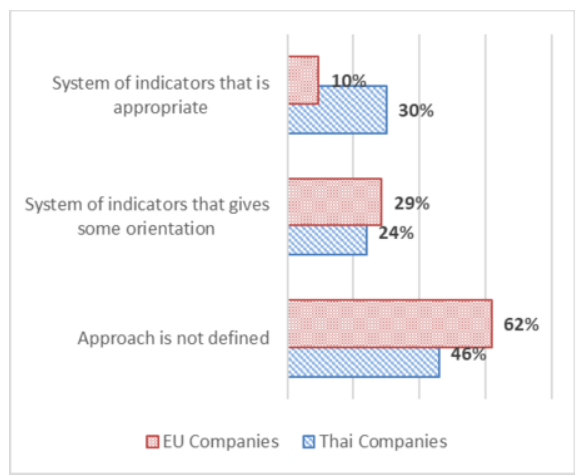

Figure 3. Utilization of indicators to track the implementation status of Industry 4.0 strategy. 


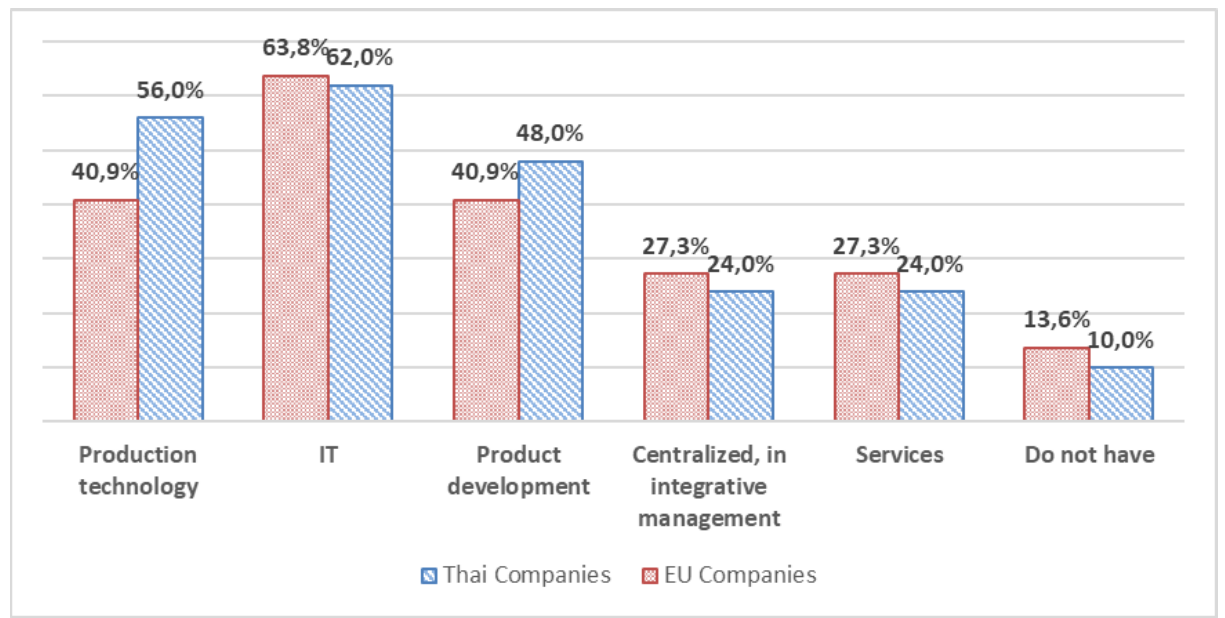

Figure 4. Areas of systematic technology and innovation management.

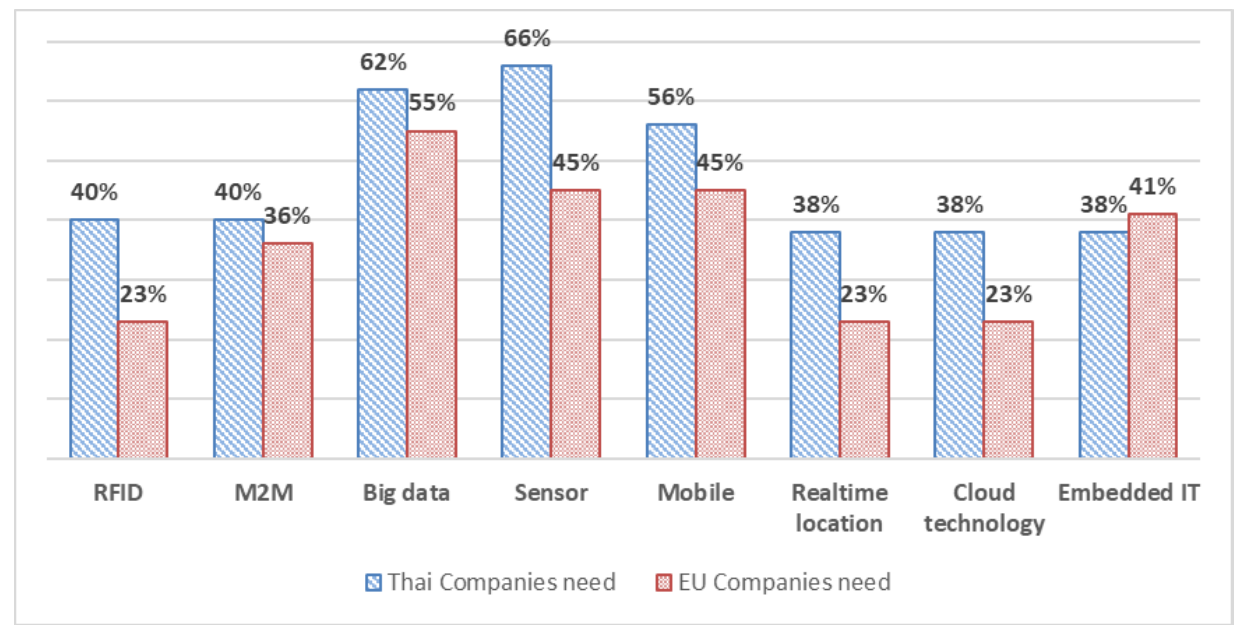

Figure 5. Levels of adoption of technologies needed.

Figures 5 and 6 present the levels of adoption of Industry 4.0 technologies. It could be observed that big data, sensors and mobile devices have been identified as the technologies essential to most of the companies for both regions. For the first two, the wide gaps between actual use and desired use levels could be observed. From the perspective of MSIE graduates, that data vows for technology specific competences and good recognition of their application in specific business circumstances.

The companies also voiced out the needs for competence staffs. According to the responses, more than $60 \%$ companies said that their existing overall employee level of competence is not adequate or non-existent for the implementation of the industry 4.0 covering both technical and transversal competences. They have been making efforts to acquire or develop their employee levels of competence to the needs of Industry 4.0. Different types of program, e.g., formal educational programs, special training seminars, knowledge transfer systems, coaching and mentoring have been pursued. 


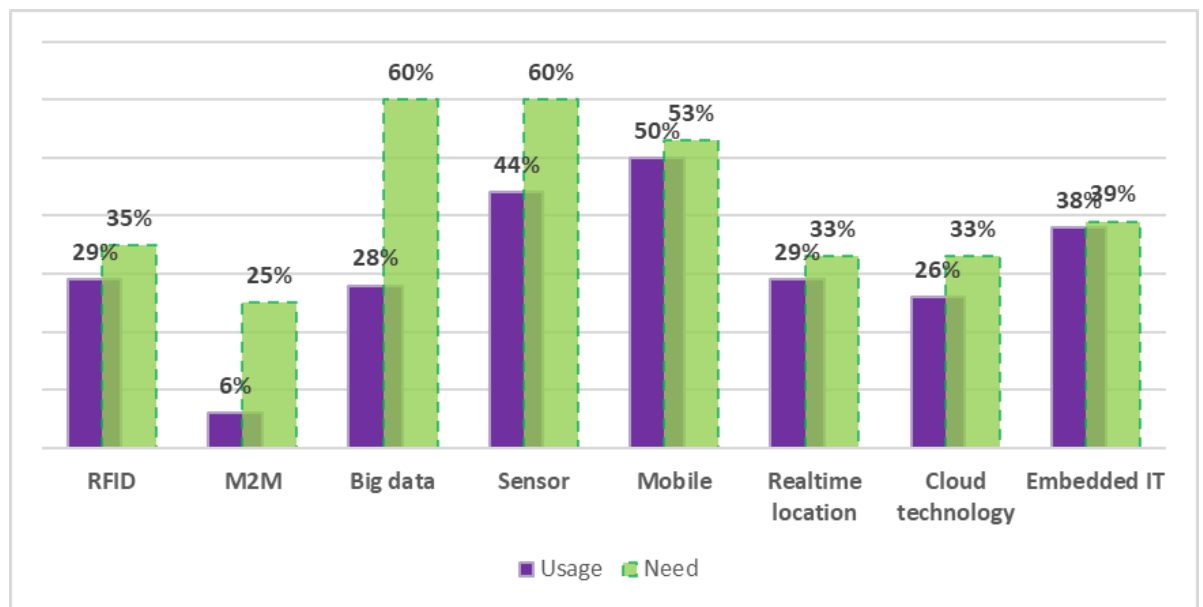

Figure 6. The gap between desired levels and current usage of Industry 4.0 technologies.

\subsection{Roles of industrial engineers}

According to the survey results, the top-three technologies the industries need to enhance their business competitiveness are big data, sensor and mobile device, and their top-three areas for attaining Industry 4.0 are production technology, product development and IT-integrated system. A cross-analysis was conducted between main technologies and main domains of applications to identify potential outcomes. For examples, the applications of big data in production technology allow companies to obtain better solutions for their industry practical problems and the employment of sensor technology in production technology allows accessibility to data in real time for operations management. The potential outcomes from the nine combinations are illustrated in Figure 7. The connection of industrial engineering to these technologies and areas of interest were also identified. The relative importance revealed the focused areas.

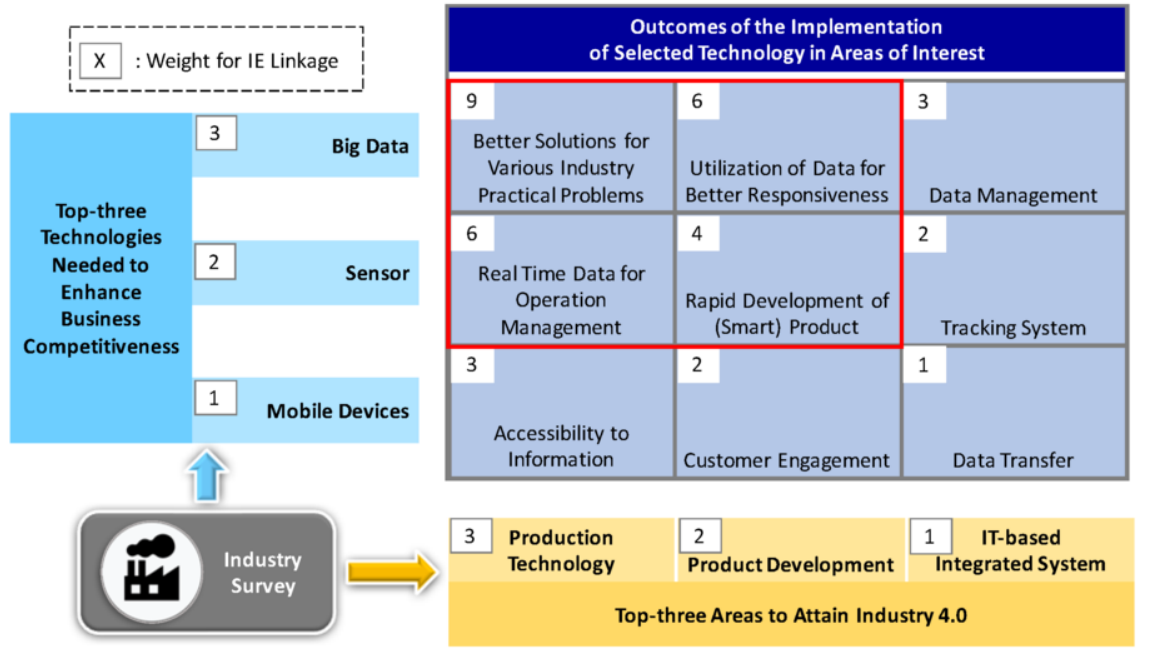

Figure 7. Potential outcomes of implementing technologies in areas of intersest to attain Industry 4.0. 
For each individual outcome, a list of applications that industrial engineers should be able to develop and deal with was developed and the different managerial roles of industrial engineers were identified by using the following classification modified from the research work of Moeuf and colleagues [7]. The managerial roles in ascending order are as follows:

- Observing

- Monitoring

- Control

- Improvement

- Autonomy.

In response to the identified roles, the expected competence levels of MSIE graduates were assessed by using Bloom's Taxonomy [8]. The competence levels in ascending order are as follows:

- Understand

- Apply

- Analyze

- Evaluate

- Create

Please note that remembering, the lowest level, was not considered because these three technologies and three domains of application were considered being highly relevant by the participant companies; thus, it was assumed they should be at least at the level of understanding.

Table 1 presents the roles of industrial engineers. According to the analysis and assessment, industrial engineers will be able to play an important role to support the companies in the application areas of big data specially in production technology. With the expected creation level of competence, the MSIE graduates should be able to in a position to help the companies improve their operation management ability. The abilities to make use of real time data in production technology and of big data in product development at high managerial levels are also anticipated.

Apart from the technical competences, transversal competences are also considered important for future MSIE graduates. In our additional survey with students, various transversal skills have been addressed, e.g., adaptability and ability to change, teamwork, communication skills, social skills, self-management and time management, and knowledge on legal affairs and sustainability. Among them, adaptability and ability to change together with teamwork and communication skills were considered the most important ones. Intuitively, the results are understandable. In a very fast changing environment nowadays in most industries, the technical knowledge learned in any course of study may become obsolete soon due to high-speed technology development and due to new requirements of customers about smart products and smart services. To cope with these trends, future MSIE graduates must have the ability to adapt themselves with changes in technology/customer requirements/business environment through self-studying and enhancing their problem-solving skills. Also, in order to work in interdisciplinary teams on various types of project addressing different problems under Industry 4.0 requirements, MSIE graduates should not only equip themselves with knowledge on IE \& non-IE technical subjects in order to perform efficiently in the teams, their ability to communicate effectively with other team members/customers or high management level is also in need. In fact, the transversal skills have been incorporated implicitly in traditional IE curricula of various academic 
Table 1. Roles of MSIE Graduates.

\begin{tabular}{|c|c|c|c|c|c|}
\hline $\begin{array}{l}\text { Main } \\
\text { technologies }\end{array}$ & $\begin{array}{l}\text { Main areas } \\
\text { of } \\
\text { application }\end{array}$ & Outcomes & Applications & $\begin{array}{l}\text { Roles of } \\
\text { MSIE } \\
\text { Graduates } \\
\end{array}$ & $\begin{array}{l}\text { Competence } \\
\text { Level }\end{array}$ \\
\hline Big Data & $\begin{array}{l}\text { Production } \\
\text { Technology }\end{array}$ & $\begin{array}{l}\text { Better Solution } \\
\text { for Various } \\
\text { Industry } \\
\text { Practical } \\
\text { Problems }\end{array}$ & $\begin{array}{l}\text { Data Analytics } \\
\text { Quality Management } \\
\text { Flexible Production Planning and } \\
\text { Scheduling for Demand Changes } \\
\text { and Customization } \\
\text { Trend analysis } \\
\text { Data Distribution } \\
\text { Logistic and supply chain } \\
\text { management } \\
\text { Forecasting } \\
\text { Inventory Management } \\
\text { Maintenance Management }\end{array}$ & $\begin{array}{l}\text { Improvement } \\
\text { Improvement } \\
\text { Improvement } \\
\text { Improvement } \\
\text { Improvement } \\
\text { Improvement }\end{array}$ & $\begin{array}{l}\text { Create } \\
\text { Create } \\
\text { Create } \\
\text { Create } \\
\text { Create } \\
\text { Create }\end{array}$ \\
\hline Big Data & $\begin{array}{l}\text { Product } \\
\text { Development }\end{array}$ & $\begin{array}{l}\text { Utilization of } \\
\text { Data for Better } \\
\text { Responsiveness }\end{array}$ & $\begin{array}{l}\text { Customer Need Analysis } \\
\text { Product Life Cycle Assessment } \\
\text { Business Process Modeling } \\
\text { QFD and FMEA }\end{array}$ & $\begin{array}{l}\text { Control } \\
\text { Control } \\
\text { Control } \\
\text { Control } \\
\end{array}$ & $\begin{array}{l}\text { Analyze } \\
\text { Apply } \\
\text { Apply } \\
\text { Analyze }\end{array}$ \\
\hline Big Data & $\begin{array}{l}\text { IT-based } \\
\text { Integrated } \\
\text { System }\end{array}$ & $\begin{array}{l}\text { Data } \\
\text { Management }\end{array}$ & $\begin{array}{l}\text { Data Retrieval and Filtering } \\
\text { Data Mining } \\
\text { Data Envelopment Analysis } \\
\text { Resources Allocation }\end{array}$ & $\begin{array}{l}\text { Observing } \\
\text { Observing } \\
\text { Monitoring } \\
\text { Control }\end{array}$ & $\begin{array}{l}\text { Apply } \\
\text { Apply } \\
\text { Apply } \\
\text { Analyze }\end{array}$ \\
\hline Sensor & $\begin{array}{l}\text { Production } \\
\text { Technology }\end{array}$ & $\begin{array}{l}\text { Real Time Data } \\
\text { for operations } \\
\text { management }\end{array}$ & $\begin{array}{l}\text { Shop Floor Control } \\
\text { Condition Based Maintenance } \\
\text { Real Time Process Control } \\
\text { Operational Safety }\end{array}$ & $\begin{array}{l}\text { Control } \\
\text { Improvement } \\
\text { Control } \\
\text { Monitoring } \\
\end{array}$ & $\begin{array}{l}\text { Apply } \\
\text { Analyze } \\
\text { Evaluate } \\
\text { Analyze } \\
\end{array}$ \\
\hline Sensor & $\begin{array}{l}\text { Product } \\
\text { Development }\end{array}$ & $\begin{array}{l}\text { Rapid } \\
\text { Development } \\
\text { of (Smart) } \\
\text { Product } \\
\end{array}$ & $\begin{array}{l}\text { Smart Product with Sensor } \\
\text { Embedded } \\
\text { Reverse Engineering } \\
\text { Virtual Laboratory and Simulation }\end{array}$ & $\begin{array}{l}\text { Monitoring } \\
\text { Monitoring }\end{array}$ & $\begin{array}{l}\text { Apply } \\
\text { Apply }\end{array}$ \\
\hline Sensor & $\begin{array}{l}\text { IT-based } \\
\text { Integrated } \\
\text { System }\end{array}$ & $\begin{array}{l}\text { Tracking } \\
\text { System }\end{array}$ & $\begin{array}{l}\text { Warehouse Operations } \\
\text { Management } \\
\text { Location Tracking in Logistic } \\
\text { Management } \\
\text { Automatic Guided Control System } \\
\text { Remote Monitoring and Control } \\
\text { Functions of Product for Service }\end{array}$ & $\begin{array}{l}\text { Monitoring } \\
\text { Monitoring } \\
\text { Monitoring } \\
\text { Monitoring }\end{array}$ & $\begin{array}{l}\text { Analyze } \\
\text { Analyze } \\
\text { Analyze } \\
\text { Analyze }\end{array}$ \\
\hline $\begin{array}{l}\text { Mobile } \\
\text { Devices }\end{array}$ & $\begin{array}{l}\text { Production } \\
\text { Technology }\end{array}$ & $\begin{array}{l}\text { Accessibility to } \\
\text { Information }\end{array}$ & $\begin{array}{l}\text { Remote Monitoring } \\
\text { Interactive Communication }\end{array}$ & $\begin{array}{l}\text { Monitoring } \\
\text { Monitoring }\end{array}$ & $\begin{array}{l}\text { Apply } \\
\text { Apply }\end{array}$ \\
\hline $\begin{array}{l}\text { Mobile } \\
\text { Devices }\end{array}$ & $\begin{array}{l}\text { Product } \\
\text { Development }\end{array}$ & $\begin{array}{l}\text { Customer } \\
\text { Engagement }\end{array}$ & Co-created Design & Control & Apply \\
\hline $\begin{array}{l}\text { Mobile } \\
\text { Devices }\end{array}$ & $\begin{array}{l}\text { IT-based } \\
\text { Integrated } \\
\text { System }\end{array}$ & Data Transfer & Data Transfer & Monitoring & Apply \\
\hline
\end{tabular}

institutions. However, in the existence of new and challenging requirements of Industry 4.0 , especially in the context of Thailand sustainable smart industry, those transversal skills should be enhanced and incorporated explicitly through the introduction of active teaching and learning approaches in the curricula.

\section{Conclusions}

In the view of industry, three key technologies needed to enhance their competitiveness are big data, sensors and mobile devices, and their areas of interest to attain Industry 
4.0 are production technology, product development and IT systems. Industrial engineers are expected to play an important role in utilizing these technologies to obtain better solutions for various industrial problems and to provide better responsiveness and effective operation management. Both technical and transveral competences are expected also from MSIE graduates. Since the questionaire was not specific for industrial engineering discipline, other disciplines can also identified their roles from the obtained survey results.

\section{Acknowledgement}

This work is the outcome of project "Curriculum Development of Master's Degree Program in Industrial Engineering for Thailand Sustainable Smart Industry (MSIE 4.0)" that has been funded with support from the European Commission (Project Number: 586137-EPP-1-2017-1-TH-EPPKA2-CBHE-JP). This publication reflects the views only of the authors, and the Commission cannot be held responsible for any use which may be made of the information contained therein.

\section{References}

[1] M. Yorke, Employability in Higher Education: What It Is, What It Is Not, Learning and Employability Series 1, Higher Education Academy, York, 2006, Available: https://www.heacademy.ac.uk/sites/default/files/id116_employability_in_higher_education_336.pdf.

[2] R.M. Lima, et al., Development of Competences While Solving Real Industrial Interdisciplinary Problems: A Successful Cooperation With Industry, Production Journal, vol. 27(spe), pp. 1-14, 2017. doi: $10.1590 / 0103-6513.230016$

[3] R.M. Lima, et al., Defining the Industrial and Engineering Management Professional Profile: A Longitudinal Study Based on Job Advertisements, Production Journal, vol. 27(spe), pp. 1-15, 2017. doi:10.1590/0103-6513.229916

[4] R.M. Lima, et al., An Analysis of Knowledge Areas in Industrial Engineering and Management Curriculum, International Journal of Industrial Engineering and Management, vol. 3(2), pp. 75-82, 2012

[5] K, Lichtblau, et al., 2015, Industrie 4.0 Readiness. Accessed: 17.03.2019. [Online]. Available: https://www.industrie40-readiness.de/?lang=en

[6] PwC. (2018). Industry 4.0 Self-Assessment. Accessed: 10.05.2018. [Online]. Available: https://i40selfassessment.pwc.de/i40/landing/

[7] A. Moeuf, et al., The Industrial Management of SMEs in the Era of Industry 4.0, International Journal of Production Research, vol. 56(3), pp. 1118-1136, 2018. doi:10.1080/00207543.2017.1372647

[8] D.R. Krathwohl, A Revision of Bloom's Taxonomy: An overview, Theory into Practice, vol. 41(4), pp. 212-218, 2002. 